\title{
Upaya Penurunan Aktivitas Seksual Pranikah Melalui Pendidikan Kesehatan Reproduksi Berbasis Kesetaraan Gender
}

\author{
Ika Parmawati ${ }^{1 *}$, Wenny Artanty Nisman ${ }^{2}$, Wiwin Lismidiati ${ }^{3}$, Sri Mulyani ${ }^{4}$ \\ ${ }_{1,2,3}$ Departemen Keperawatan Anak dan Maternitas, Fakultas Kedokteran, Kesehatan Masyarakat, dan \\ Keperawatan, Universitas Gadjah Mada \\ ${ }^{4}$ Departemen Kesehatan Mental dan Keperawatan Masyarakat, Fakultas Kedokteran, Kesehatan Masyarakat, \\ dan Keperawatan, Universitas Gadjah Mada
}

Submisi: 15 Agustus 2018 ; Revisi: 12 Februari 2020; Penerimaan: 13 Februari 2020

Kata Kuinci: Abstralk Perkembangan organ reproduksi dan ketidaksetaraan peran gender Efikasi diri Gender Pengetahuan Remaja Sikap dalam masyarakat meningkatkan kerentanan remaja putri untuk mengalami pemaksaan seksual. Pendidikan kesehatan reproduksi yang membahas kesetaraan gender diketahui dapat membantu remaja dalam mengontrol dorongan seksual dan menurunkan kejadian pemaksaan seksual. Sasaran kegiatan pengabdian ini adalah 64 siswi di salah satu Sekolah Menengah Kejuruan di Kabupaten Kulon Progo. Pendidikan kesehatan reproduksi berbasis kesetaraan gender disampaikan melalui metode diskusi kelompok kecil (focus group discussion) dengan modul, konsultasi pribadi dengan media elektronik, dan ceramah yang dilaksanakan pada September 2017. Skor pengetahuan, sikap, dan efikasi diri remaja yang diperoleh melalui pre-test dan post-test diuji normalitasnya dengan One-Sample Kolmogorov-Smirnov Test dan dianalisis dengan uji Wilcoxon dengan taraf kepercayaan 95\%. Hasilnya menunjukkan bahwa terdapat perbedaan yang signifikan dalam hal pengetahuan, sikap, dan efikasi diri tentang seksual kesehatan reproduksi antara sebelum dan sesudah pelaksanaan pendidikan kesehatan reproduksi berbasis kesetaraan gender dengan $p$-value $(p)<0,05$. Skor pengetahuan, sikap, dan efikasi diri seksual setelah pelaksanaan pendidikan kesehatan lebih besar daripada sebelum pendidikan kesehatan dilaksanakan. Dengan demikian, pelaksanaan pendidikan kesehatan reproduksi berbasis kesetaraan gender dapat meningkatkan pengetahuan, sikap, dan efikasi diri remaja putri.

Keywords: $\quad$ Abstract Reproductive organ development and gender inequality in the Adolescence Attitude Gender Knowledge Self-efficacy community increase the vulnerability of adolescent girls to sexual coercion. Gender-sensitive reproductive health education is known to be able to control adolescent sexual urges and reduce the incidence of sexual coercion. The sample was 64 adolescent girls at one of the Vocational High Schools in Kulon Progo Regency. The reproductive health education based on gender ideology was given through a focus group discussion method with a module, personal consultation with electronic media, and lecture in September 2017. The knowledge, attitudes, and self-efficacy scores of adolescents obtained through pretest and posttest were tested for normality by One-Sample KolmogorovSmirnov Test and analyzed by the Wilcoxon test with a 95\% confidence level. The results showed significant differences in knowledge, attitudes, and sexual self-efficacy of reproductive health between pre-and post-reproductive health

ISSN 2460-9447 (print), ISSN 2541-5883 (online)

${ }^{*}$ Corresponding author : Ika Parmawati

Departemen Keperawatan Anak dan Maternitas, Fakultas Kedokteran, Kesehatan Masyarakat, dan Keperawatan, Universitas Gadjah Mada, J.Farmako Sekip Utara, Depok, Sleman, Daerah Istimewa Yogyakarta, Indonesia Email: ika.parmawati@mail.ugm.ac.id 
education based on gender equality with $p$-value $(p)<0.05$. The score of knowledge, attitudes, and sexual self-efficacy after health education is greater than before health education. Thus, the provision of reproductive health education based on gender equality can improve the knowledge, attitudes, and self-efficacy of young women.

\section{PENDAHULUAN}

Definisi remaja menurut Peraturan Menteri Kesehatan Republik Indonesia Nomor 25 Tahun 2014 adalah individu yang berusia 10-18 tahun (Kemenkes RI, 2014). Proporsi jumlah remaja Indonesia pada 2016 dalam piramida penduduk cukup besar, yaitu 25,63\% (Kemenkes RI, 2017). Pada 2012, jumlah remaja di Yogyakarta adalah 15,15\% (Dinas Kesehatan Daerah Istimewa Yogyakarta, 2013). Adapun jumlah anak berusia 10-19 tahun di Kabupaten Kulon Progo pada 2015 mencapai 58.417 orang atau 13,99\% (Dinas Kesehatan Kabupaten Kulon Progo, 2016).

Salah satu bentuk pertumbuhan dan perkembangan remaja adalah adanya kematangan organ reproduksi (Krohmer, 2010). Remaja mengalami kerentanan dalam menentukan pilihan kesehatan reproduksi karena adanya hambatan sosial dan sistem kesehatan (Kyilleh et al., 2018). Faktor yang memengaruhi kesehatan reproduksi, antara lain, stigma, informasi kesehatan, diskriminasi, kekerasan, dan pelayanan kesehatan (Idele et al., 2014).

Kyilleh et al. (2018) mengatakan bahwa rendahnya pengetahuan dan akses remaja terhadap pelayanan kesehatan reproduksi meningkatkan risiko terjadinya kehamilan yang tidak diinginkan, aborsi yang tidak aman dan komplikasinya, serta infeksi menular seksual. Pada 2008 terdapat lebih dari empat puluh juta remaja Indonesia yang mengalami HIV/AIDS, infeksi menular seksual, menggunakan obat terlarang, mengalami kehamilan yang tidak diinginkan, melakukan aborsi yang tidak aman, dan anemia defisiensi besi akibat perubahan gaya hidup, rendahnya pengetahuan tentang kesehatan reproduksi, dan kurangnya kualitas pelayanan kesehatan reproduksi remaja (Sammon et al., 2017).

Pada 2010, angka kematian ibu remaja berusia 13-14 tahun tergolong tinggi. Antara 2011-2015 terdapat peningkatan jumlah remaja usia 15-19 tahun yang mengalami HIV, yaitu $13.1 \%$ (Sammon et al., 2017). Badan Penelitian dan Pengembangan Kesehatan (2013) mencatat bahwa $1,97 \%$ kehamilan remaja terjadi pada usia 15-19 tahun. Terkait hal tersebut, angka pernikahan dini di Yogyakarta pada 2013 mencapai 434 kasus (Ghojali, 2014). Ketidaksetaraan gender dalam masyarakat meningkatkan risiko HIV, pernikahan dini, kehamilan, dan kekerasan seksual pada remaja putri. Stereotip norma gender dalam masyarakat membentuk laki-laki untuk lebih aktif secara seksual dan perempuan lebih dibatasi. Selain itu, perempuan bertanggung jawab terhadap pencegahan kehamilan (Ninsiima et al., 2018). Budaya yang mengunggulkan laki-laki membentuk pandangan negatif tentang fungsi, peran, dan kedudukan perempuan (Sugihastuti \& Saptiawan, 2010).

Ninsiima et al. (2018) mengatakan bahwa dibutuhkan program yang bertujuan untuk mengubah perilaku remaja sejak awal dengan mengajarkan kesetaraan gender dan menciptakan lingkungan yang mendukung kesejahteraan remaja. Pendidikan reproduksi yang membahas kesetaraan gender dapat mempromosikan keadilan gender; meningkatkan keamanan hubungan; mengontrol dorongan seksual; membentuk pengetahuan, sikap, dan perilaku sehat; mengembangkan motivasi dan efikasi kontrol diri; mengubah sikap dan keyakinan yang berkaitan dengan peran gender; menurunkan pemaksaan dan pelecehan seksual; serta meningkatkan pemberdayaan remaja (Muhanguzi, 2011; Timreck, 2004; BKKBN, 2012; Grose, Grabe, \& Kohfeldt, 2014; Kernsmith \& Jozefowics, 2011).

Kulon Progo merupakan salah satu kabupaten di Provinsi Yogyakarta yang memiliki karakteristik wilayah berupa pantai hingga pegunungan. Salah satu kecamatan di Kulon Progo yang berkarakteristik perbukitan adalah Kecamatan Nanggulan. Kecamatan Nanggulan memiliki kepadatan penduduk cukup tinggi, yaitu 712 jiwa $/ \mathrm{km}^{2}$. Pada 2015, enam bayi meninggal di wilayah kerja Puskesmas Nanggulan. Jumlah tersebut merupakan tertinggi kedua di Kulon Progo pada 2015.

Dinas Kesehatan Kabupaten Kulon Progo (2014) menyatakan bahwa pada 2013 terdapat 261 kasus kehamilan remaja dan 84 kasus persalinan remaja. Masalah tersebut belum teratasi hingga tahun berikutnya karena angka kehamilan remaja pada 2014 sebanyak 206 dan mayoritas berusia 15-19 tahun. Dari data tersebut diketahui bahwa Kecamatan Nanggulan memiliki angka kehamilan remaja tertinggi pertama pada 2014. World Health Organization (2018) menyatakan bahwa kehamilan remaja dapat menyebabkan beberapa komplikasi, aborsi tidak aman, peningkatan risiko pre-eklampsia, puerperal endometritis, infeksi sistemis, risiko berat badan lahir bayi rendah, persalinan prematur, gangguan berat pada neonatus, dan kematian.

Remaja di sekolah belum mendapatkan pendidikan kesehatan reproduksi secara rutin dari 
tenaga kesehatan atau guru sekolah. Puskesmas di wilayah Kabupaten Kulon Progo bertanggung jawab terhadap kesehatan siswa di wilayah kerjanya. Namun demikian, upaya promotif dan preventif terhadap masalah kesehatan reproduksi remaja di sekolah masih terbatas pada pemberian pendidikan kesehatan reproduksi kepada setiap siswa baru ketika awal masuk sekolah. Dengan demikian, dibutuhkan upaya pendidikan kesehatan yang rutin serta partisipasi dan regenerasi dari siswa untuk menjadi kader kesehatan reproduksi di sekolah.

Berdasarkan hal tersebut, kegiatan pengabdian ini bertujuan untuk meningkatkan pengetahuan, sikap, dan efikasi remaja putri tentang kesehatan reproduksi melalui pendidikan kesehatan berbasis kesetaraan gender sehingga dapat mencegah aktivitas seksual pranikah. Selain itu, pengabdian ini juga bertujuan untuk meningkatkan kesadaran remaja putri tentang ketidaksetaraan gender dalam masyarakat yang dapat meningkatkan risiko pemaksaan aktivitas seksual.

\section{METODE}

Subjek dalam kegiatan pengabdian ini adalah 64 siswa putri di Sekolah Menengah Kejuruan Negeri 1 Nanggulan, Kabupaten Kulon Progo. Kegiatan dilaksanakan dengan metode pendidikan kesehatan, media pendidikan kesehatan berupa modul kesehatan reproduksi berbasis kesetaraan gender, dan kuesioner pengetahuan, sikap, serta efikasi diri seksual yang telah dikembangkan oleh Parmawati (2015) dalam penelitiannya yang berjudul "Pengaruh Pendidikan Kesehatan Reproduksi Berbasis Kesetaraan Gender dalam Meningkatkan Pengetahuan, Sikap, dan Efikasi Diri Remaja Putri di Wilayah Kerja Puskesmas Temon 1 Kulon Progo Yogyakarta". Metode pendidikan kesehatan yang digunakan dalam kegiatan pengabdian ini adalah diskusi kelompok kecil (focus group discussion) dengan media modul kesehatan reproduksi, konsultasi pribadi dengan media elektronik, dan ceramah.

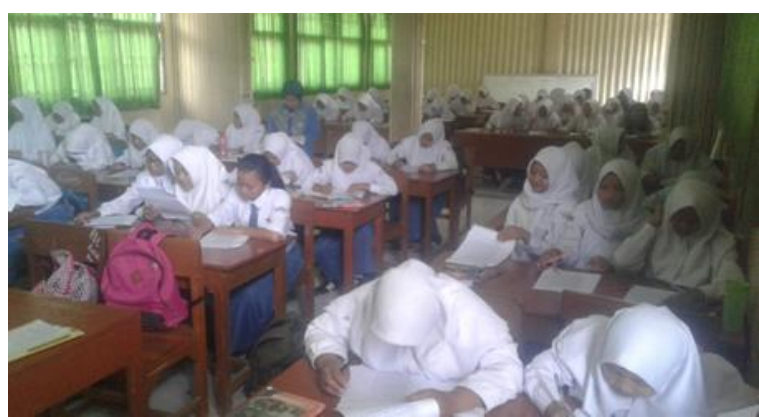

Gambar 1. Kegiatan pre-test perubahan pada masa pubertas

Kegiatan pendidikan kesehatan dilaksanakan dua kali, yaitu pada 13 dan 27 September 2017. Pada pertemuan pertama, kegiatan dimulai dengan perkenalan, penjelasan kegiatan dan tujuan, kontrak waktu, pre-test selama 30 menit (Gambar 1), penyampaian materi tentang perubahan pada masa Vol. 6, No. 1, Indonesian Journal of Community Engagement pubertas serta tanya jawab selama 45 menit, dan dilanjutkan dengan diskusi kesehatan reproduksi berbasis kesetaraan gender dalam kelompok selama 45 menit (Gambar 2). Pada saat diskusi kelompok, 64 siswa dibagi menjadi 5 kelompok dan didampingi oleh fasilitator untuk mendiskusikan kasus yang telah disediakan dalam modul. Siswa diberi modul tentang kesehatan reproduksi berbasis kesetaraan gender. Setelah diskusi kelompok selesai, fasilitator memberikan contact person kepada siswa dalam masing-masing kelompok dan mempersilakan siswa untuk menghubungi jika mengalami kesulitan dalam memahami isi modul atau jika ingin melakukan konseling. Pertemuan kedua dilaksanakan dua minggu setelah pertemuan pertama. Kegiatan dimulai dengan penyampaian materi tentang kesetaraan gender (45 menit) dan post-test (45 menit).

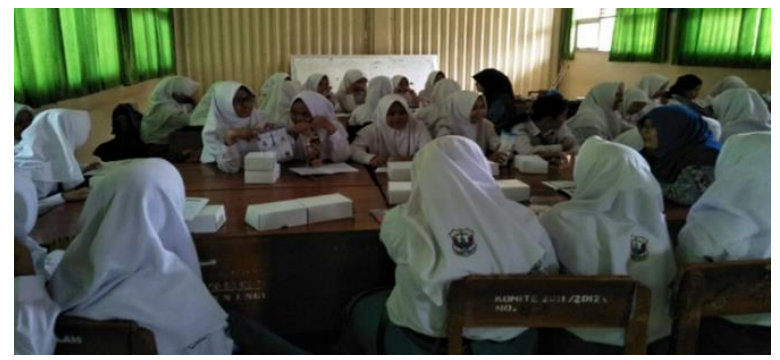

Gambar 2. Kegiatan FGD kesehatan reproduksi berbasis kesetaraan gender

Karakteristik responden berupa data numerik (usia, usia menarche, pengalaman pacaran, kelas) yang dianalisis dengan frekuensi, persentase, rata-rata, nilai minimum, dan nilai maksimum. Adapun data nominal dan ordinal (tempat tinggal, pengalaman mendapatkan informasi kesehatan reproduksi, pengalaman melakukan aktivitas seksual) dianalisis dengan frekuensi dan persentase skor pengetahuan, sikap, serta efikasi diri remaja yang diuji normalitasnya.

\section{HASIL DAN PEMBAHASAN}

\subsection{Karakteristik sasaran}

Berdasarkan hasil pengambilan data diketahui bahwa sebagian besar responden adalah kelas XI (51,6\%), berusia 16 tahun $(43,8 \%)$, mendapatkan menstruasi pertama pada usia 13 tahun $(46,9 \%)$, dan pernah pacaran sebanyak 1 kali (21,9\%). Rahmawati et al. (2017) dalam penelitiannya menyebutkan bahwa ratarata usia menarke adalah $12.01 \pm 0.89$ untuk remaja perkotaan dan $12.97 \pm 0.91$ untuk remaja pedesaan (Tabel 1).

Tabel 1. Karakteristik sasaran berdasarkan karakteristik usia, usia menarche, pengalaman pacaran, dan kelas

\begin{tabular}{cccccc}
\hline Karakteristik & f & \% & Mean & Minimum & Maximum \\
\hline Usia & & & 15.7188 & 15 & 17 \\
15 tahun & 27 & 42.2 & & & \\
16 tahun & 28 & 43.8 & & & \\
17 tahun & 9 & 14.1 & & & \\
\hline Total & 64 & 100.0 & & &
\end{tabular}

WWW.jurnal.ugm.ac.id/jpkm 40 
Lanjutan Tabel 1

\begin{tabular}{cccccc}
\hline Karakteristik & f & $\%$ & Mean & \multicolumn{2}{c}{ Minimum Maximum } \\
\hline Usia & & & 12.6250 & 19 & 15 \\
Menarche & & & & & \\
9 tahun & 1 & 1.6 & & \\
10 tahun & 1 & 1.6 & & \\
11 tahun & 6 & 9.4 & & \\
12 tahun & 16 & 25.0 & & \\
13 tahun & 30 & 46.9 & & \\
14 tahun & 9 & 14.1 & & \\
15 tahun & 1 & 1.6 & & \\
\hline Total & 64 & 100.0 & & & \\
\hline Pengalaman & & & 2.0313 & 0 & 11 \\
Pacaran & 21 & 32.8 & & & \\
0 kali & 14 & 21.9 & & \\
1 kali & 8 & 12.5 & & \\
2 kali & 9 & 14.1 & & \\
3 kali & 3 & 4.7 & & \\
4 kali & 3 & 4.7 & & \\
5 kali & 3 & 4.7 & & \\
6 kali & 1 & 1.6 & & \\
8 kali & 1 & 1.6 & & \\
9 kali & 1 & 1.6 & & \\
11 kali & & & & \\
\hline Total & 64 & 100.0 & & \\
\hline Kelas & & & & \\
X & 31 & 48.4 & & \\
XI & 33 & 51.6 & & \\
\hline Total & 64 & 100.0 & & \\
\hline Sebagian & & & \\
\hline
\end{tabular}

Sebagian besar peserta pendidikan kesehatan reproduksi $(89,1 \%)$ tinggal dengan orang tua dan semua pernah mendapatkan pendidikan kesehatan reproduksi (Tabel 2). Pendidikan kesehatan reproduksi yang diperoleh, antara lain, berasal dari penyuluhan puskesmas $(95,3 \%)$, seminar $(28,1 \%)$, dan media massa cetak/elektronik (57,8\%). Media massa yang disebutkan adalah internet dan televisi. Von-Rosen et al. (2017) mengatakan bahwa siswa cenderung lebih mudah memahami sumber informasi online.

Tabel 2. Karakteristik sasaran berdasarkan karakteristik tempat tinggal, pendidikan kesehatan reproduksi yang telah didapat, dan aktivitas seksual yang pernah dilakukan

\begin{tabular}{|c|c|c|c|}
\hline \multicolumn{2}{|c|}{ Karakteristik } & $\mathbf{f}$ & $\%$ \\
\hline \multirow{5}{*}{$\begin{array}{l}\text { Tempat } \\
\text { Tinggal }\end{array}$} & Orang Tua & 57 & 89.1 \\
\hline & Kakek/ Nenek & 1 & 1.6 \\
\hline & Kos & 3 & 4.7 \\
\hline & $\begin{array}{l}\text { Lainnya: Paman, Bibi, } \\
\text { Bude, Pakde, } \\
\text { Pesantren }\end{array}$ & 3 & 4.7 \\
\hline & Total & 64 & 100.0 \\
\hline \multirow{9}{*}{$\begin{array}{c}\text { Pendidikan } \\
\text { Kesehatan } \\
\text { Reproduksi } \\
\text { yang } \\
\text { Pernah } \\
\text { Didapat }\end{array}$} & Penyuluhan & 3 & 4.7 \\
\hline & $\begin{array}{l}\text { Tidak pernah } \\
\text { Pernah }\end{array}$ & 61 & 95.3 \\
\hline & Total & 64 & 100.0 \\
\hline & Seminar & 46 & 71.9 \\
\hline & $\begin{array}{l}\text { Tidak pernah } \\
\text { Pernah }\end{array}$ & 18 & 28.1 \\
\hline & Total & 64 & 100.0 \\
\hline & Media massa & 27 & 42.2 \\
\hline & $\begin{array}{l}\text { Tidak pernah } \\
\text { Pernah }\end{array}$ & 37 & 57.8 \\
\hline & Total & 64 & 100.0 \\
\hline
\end{tabular}

Berdasarkan Tabel 3 diketahui bahwa beberapa peserta menyatakan pernah melakukan aktivitas seksual selama pacaran, antara lain, berpegangan tangan (57,8\%), memeluk atau dipeluk $(23,4 \%)$, mencium atau dicium $(15,6 \%)$, dan berpelukan $(4,7 \%)$. Semua peserta menyatakan belum pernah menyentuh organ kemaluan pasangan dengan masih menggunakan pakaian atau tanpa menggunakan pakaian dan belum pernah berhubungan seksual. Oladeji \& Ayangunna (2017) menyatakan bahwa terdapat hubungan yang signifikan antara penggunaan internet, facebook, video, telepon, televisi, twitter, majalah/koran, komputer, media pornografi, dan musik dengan perilaku seksual berisiko pada remaja. Selain itu, juga terdapat hubungan yang signifikan antara pacaran, oral seks, hubungan seksual, penggunaan kondom, pergantian pasangan, pesta malam, aborsi, dan perilaku seksual berisiko pada remaja. Pengalaman melakukan aktivitas seksual dengan lawan jenis meningkatkan risiko remaja untuk melakukan aktivitas seksual dengan lebih sering.

Tabel 3. Karakteristik sasaran berdasarkan aktivitas seksual yang pernah dilakukan

\begin{tabular}{|c|c|c|c|}
\hline \multirow{2}{*}{$\begin{array}{c}\text { Jenis Aktivitas } \\
\text { Seksual }\end{array}$} & \multicolumn{2}{|c|}{$\begin{array}{c}\text { Pengalaman } \\
\text { Melakukan Aktivitas } \\
\text { Seksual } \\
\end{array}$} & \multirow[t]{2}{*}{ Jumlah } \\
\hline & $\begin{array}{c}\text { Tidak } \\
\text { Pernah }\end{array}$ & Pernah & \\
\hline $\begin{array}{c}\text { Berpegangan } \\
\text { tangan }\end{array}$ & $27(42,2 \%)$ & $37(57,8 \%)$ & $64(100 \%)$ \\
\hline $\begin{array}{l}\text { Memeluk atau } \\
\text { dipeluk }\end{array}$ & $49(76,6 \%)$ & $15(23,4 \%)$ & $64(100 \%)$ \\
\hline $\begin{array}{l}\text { Mencium atau } \\
\text { dicium }\end{array}$ & $54(84,4 \%)$ & $10(15,6 \%)$ & $64(100 \%)$ \\
\hline Berpelukan & $61(95,3 \%)$ & $3(4,7 \%)$ & $64(100 \%)$ \\
\hline $\begin{array}{l}\text { Menyentuh } \\
\text { kemaluan }\end{array}$ & $64(100 \%)$ & $0(0 \%)$ & $64(100 \%)$ \\
\hline $\begin{array}{l}\text { dengan masih } \\
\text { menggunakan } \\
\text { pakaian }\end{array}$ & & & \\
\hline $\begin{array}{l}\text { Menyentuh } \\
\text { kemaluan } \\
\text { dengan tanpa } \\
\text { menggunakan } \\
\text { pakaian }\end{array}$ & $64(100 \%)$ & $0(0 \%)$ & $64(100 \%)$ \\
\hline $\begin{array}{c}\text { Hubungan } \\
\text { seksual }\end{array}$ & $64(100 \%)$ & $0(0 \%)$ & $64(100 \%)$ \\
\hline
\end{tabular}

Jumlah peserta pendidikan kesehatan reproduksi berbasis kesetaraan gender adalah 64 orang. Dengan uji Wilcoxon diperoleh nilai significancy $(P)<0,05$. Dengan demikian, dapat disimpulkan bahwa terdapat perbedaan pengetahuan, sikap, dan efikasi diri seksual kesehatan reproduksi yang bermakna antara sebelum dan sesudah dilaksanakannya pendidikan kesehatan reproduksi berbasis kesetaraan gender (Tabel 4). Skor pengetahuan, sikap, dan efikasi diri seksual setelah pelaksanaan pendidikan kesehatan lebih besar daripada sebelum pendidikan kesehatan dilaksanakan. 
Tabel 4. Perbandingan skor pre-testdan post-test pengetahuan, sikap, dan efikasi diri seksual setelah pemberian pendidikan kesehatan reproduksi berbasis kesetaraan gender

\begin{tabular}{|c|c|c|c|c|}
\hline \multirow[b]{2}{*}{ Variabel } & \multicolumn{2}{|c|}{ Perubahan Skor } & \multirow[b]{2}{*}{$\Delta$ Mean \pm SD } & \multirow[b]{2}{*}{$p$-value } \\
\hline & $\begin{array}{c}\text { Pre-test } \\
\text { Mean } \pm \text { SD }\end{array}$ & $\begin{array}{c}\text { Post-test } \\
\text { Mean } \pm \text { SD }\end{array}$ & & \\
\hline $\begin{array}{l}\text { Pengetahua } \\
\text { n Kesehatan } \\
\text { Reproduksi }\end{array}$ & $\begin{array}{c}17.9063 \pm \\
2.97459\end{array}$ & $\begin{array}{c}21.4219 \pm \\
1.87553\end{array}$ & $\begin{array}{l}3.5156 \pm \\
2.73131\end{array}$ & $\begin{array}{c}\text { Asymp. Sig. } \\
\text { (2-tailed) } \\
0.000 \\
\text { Z: }-6.426^{\mathrm{b}}\end{array}$ \\
\hline $\begin{array}{c}\text { Sikap } \\
\text { Kesehatan } \\
\text { Reproduksi }\end{array}$ & $\begin{array}{c}88.4219 \pm \\
8.94570\end{array}$ & $\begin{array}{c}93.2969 \pm \\
7.27178\end{array}$ & $\begin{array}{l}4.8750 \pm \\
9.58090\end{array}$ & $\begin{array}{c}\text { Asymp. Sig. } \\
\text { (2-tailed) } \\
0.000 \\
\text { Z: }-3.805^{\mathrm{b}}\end{array}$ \\
\hline $\begin{array}{l}\text { Efikasi Diri } \\
\text { Seksual }\end{array}$ & $\begin{array}{c}106.4844 \pm \\
10.63088\end{array}$ & $\begin{array}{c}110.312 \pm \\
11.81051\end{array}$ & $\begin{array}{l}3.8281 \pm \\
11.23565\end{array}$ & $\begin{array}{c}\text { Asymp. Sig. } \\
\text { (2-tailed) } \\
0.001 \\
\text { Z: }-3.231^{\mathrm{b}}\end{array}$ \\
\hline
\end{tabular}

Hasil analisis tersebut menunjukkan bahwa pendidikan kesehatan reproduksi berbasis kesetaran gender berpengaruh terhadap peningkatan pengetahuan, sikap, dan efikasi diri seksual remaja di SMK N 1 Nanggulan, Kulon Progo. Matswetu \& Bhana (2018) mengatakan bahwa pendidikan dapat meningkatkan pengetahuan, dukungan, hingga mengubah norma sosial budaya yang berdasarkan ketidaksetaraan gender. Le Mat (2017) juga menyebutkan bahwa pendidikan seksual yang komprehensif (mencakup gender dan kekuasaan) sangat efektif untuk mempromosikan hak kesehatan seksual dan reproduksi sesuai kebutuhan laki-laki dan perempuan. Pendidikan kesehatan dapat berupa informasi, keterampilan, nilai positif untuk dapat memahami dan menikmati seksualitas, mempunyai hubungan yang aman, serta bertanggung jawab terhadap kesehatan dan kesejahteraan seksual, baik individu maupun orang lain (Ketting \& Ivanova, 2018).

Pendidikan kesehatan reproduksi yang dilakukan di sekolah mempunyai hubungan positif dengan pengetahuan kesehatan reproduksi. Rendahnya pengetahuan tentang kesehatan reproduksi berhubungan dengan tingginya prevalensi perilaku seksual berisiko, seperti hubungan seksual yang tidak aman, kehamilan yang tidak diinginkan, dan aborsi ( $\mathrm{Li}$, C. et al., 2017). Pendidikan kesehatan reproduksi yang komprehensif akan membantu remaja untuk membentuk pengetahuan, sikap, keterampilan, dan nilai positif (hak asasi, kesetaraan gender, perbedaan, sikap dan keterampilan yang berkontribusi terhadap hubungan yang aman, sehat, dan positif) serta membantu remaja untuk dapat merefleksikan norma sosial, nilai budaya dan keyakinan tradisional ketika berhubungan dengan teman sebaya, orang tua, guru, dan orang lain dalam masyarakat (UNESCO, 2018).

Pringle et al. (2017) menyatakan bahwa remaja membutuhkan intervensi pendidikan kesehatan reproduksi yang memperhatikan perbedaan gender. Pengaruh faktor fisiologis (seperti perubahan hormonal dan perkembangan otak) terhadap kematangan seksual remaja tidak dapat dimodifikasi sehingga dibutuhkan peningkatan pemahaman tentang pengaruh faktor yang dapat dimodifikasi, seperti teman sebaya dan pengaruh sosial dalam pengembangan intervensi. Pengembangan intervensi harus melibatkan aspek sosial budaya dan agama serta diberikan berdasarkan kematangan fisiologis.

Matswetu \& Bhana (2018) mengatakan bahwa seorang guru harus mampu menjelaskan pengaruh norma budaya, ketidaksetaraan gender, dan nilai individu terhadap pengambilan keputusan seseorang. Kesetaraan gender berarti bahwa laki-laki dan perempuan mempunyai hak dan kesempatan yang sama dalam ketertarikan, kebutuhan, serta prioritas sehingga bebas untuk mengembangkan diri dan mengambil keputusan yang dibatasi peran gender. Adanya ketidaksetaraan gender menyebabkan remaja perempuan berisiko mengalami kekerasan rumah tangga dan seksual (Human Rights Initiative, 2017).

Matswetu dan Bhana (2018) menjelaskan bahwa salah satu dampak ketidaksetaraan gender adalah aktivitas seksual pranikah yang menyebabkan kehamilan, dikeluarkan dari sekolah, berkurangnya kesempatan kerja yang berhubungan dengan kemiskinan, ketergantungan kepada laki-laki, dan penyebaran infeksi HIV. Pendidikan kesehatan reproduksi dengan pendekatan sensitif gender mencakup pemberdayaan perempuan dalam diskusi antarpasangan (Li, C. et al., 2017). Pendidikan kesehatan reproduksi yang komprehensif berperan penting dalam menyiapkan remaja untuk hidup dengan aman, produktif, penuh makna, serta terhindar dari HIV/AIDS, infeksi menular seksual, kehamilan yang tidak diinginkan, dan kekerasan berbasis gender (UNESCO, 2018).

Indikator pendidikan yang komprehensif dilihat dari kesesuaian antara usia dan perkembangan. Hal tersebut bertujuan untuk meningkatkan pengetahuan, membentuk kompetensi dengan klarifikasi nilai dan norma (termasuk norma gender dan sosial), serta mengembangkan keterampilan perilaku yang protektif. Komprehensif juga terkait dengan kesesuaian topik, pentingnya memasukkan isu peran gender, perbedaan orientasi seksual, dan kontak seksual. Pendidikan kesehatan seksual tidak hanya menyampaikan pengetahuan, tetapi juga mendiskusikan norma gender dan sosial dalam mengembangkan pemikiran kritis, nilai positif, dan keterampilan perilaku (Ketting \& Ivanova, 2018). Pendidikan kesehatan reproduksi yang komprehensif adalah proses berbasis kurikulum yang mempelajari aspek kognitif, emosi, fisik, dan sosial seksualitas untuk membekali remaja dengan pengetahuan, keterampilan, sikap, dan nilai yang akan memberdayakannya untuk mencapai derajat kesehatan, kesejahteraan, mengembangkan rasa saling 
menghormati pada hubungan seksual dan sosial, menjelaskan bagaimana pilihan dapat memengaruhi kesejahteraan diri dan orang lain, serta meningkatkan pemahaman dan keyakinan terhadap perlindungan hak asasinya (UNESCO, 2018).

Pendidikan kesehatan reproduksi berbasis kesetaraan gender harus disampaikan sesuai kebutuhan tahap perkembangan remaja dan kebutuhan jenis kelamin. Pringle et al. (2017) mengatakan bahwa pengembangan intervensi pendidikan kesehatan harus memperhatikan perubahan hormonal, psikososial (teman sebaya), dan kecenderungan seksual remaja. Tingkat kesiapan masing-masing remaja untuk menerima informasi berbeda-beda. Hal itu dipengaruhi oleh gender dan kematangan fisiologis. International Planned Parenthood Federation (IPPF) menyatakan bahwa pendidikan seksualitas yang komprehensif meliputi informasi tentang semua hal yang berkaitan dengan seksualitas dan ekspresinya, antara lain, hubungan, sikap terhadap seksualitas, peran seksual, hubungan gender, tekanan sosial untuk aktif secara seksual, kontrasepsi, infeksi menular seksual, gender, dan orientasi seksual (Jiménez \& Fischer, 2017). Informasi perihal seksualitas yang disampaikan dalam pendidikan kesehatan seksual yang komprehensif atau holistis meliputi aspek kognitif, emosi, sosial, interaksi, dan fisik yang bertujuan untuk memberikan dukungan dan perlindungan terhadap perkembangan seksual (Ketting \& Ivanova, 2018).

Dalam pendidikan kesehatan berbasis kesetaraan gender dijelaskan bahwa norma gender dapat memengaruhi kesetaraan, bagaimana ketidaksetaraan dapat memengaruhi kesehatan dan kesejahteraan, dan bagaimana upaya untuk mencegah HIV, infeksi menular seksual, kehamilan remaja, dan kekerasan berbasis gender. Metode tersebut meningkatkan kesadaran tentang adanya perbedaan gender dalam kehidupan; meningkatkan rasa saling menghormati; serta membentuk hubungan yang setara berdasarkan rasa empati dan saling memahami. Integrasi perspektif gender terhadap pendidikan kesehatan reproduksi meningkatkan keefektifan program pendidikan kesehatan reproduksi (UNESCO, 2018).

\section{KESIMPULAN}

Kesimpulan dari kegiatan pengabdian di SMK N 1 Nanggulan, Kabupaten Kulon Progo adalah terdapat peningkatan pengetahuan, sikap, dan efikasi remaja putri setelah mendapatkan pendidikan kesehatan reproduksi berbasis kesetaraan gender. Pendidikan kesehatan reproduksi remaja di Sekolah Menengah Kejuruan masih sangat jarang dilakukan sehingga perlu adanya koordinasi antara guru di sekolah dan petugas kesehatan dari Puskesmas untuk dapat bekerja sama dalam melaksanakan pendidikan kesehatan reproduksi secara rutin dengan materi dan metode pendidikan kesehatan yang bervariasi. Selain itu, perlu adanya keterlibatan aktif dari guru di sekolah untuk memberikan materi pendidikan kesehatan reproduksi. Oleh karena itu, dibutuhkan pelatihan khusus tentang pendidikan kesehatan reproduksi bagi guru yang bertanggung jawab untuk memberikan konseling kesehatan di sekolah.

\section{DAFTAR PUSTAKA}

Badan Penelitian dan Pengembangan Kesehatan. (2013). Riset Kesehatan Dasar 2013. Kementerian Kesehatan Indonesia. Diakses dari http://www.litbang. depkes.go.id/sites/download/rkd2013/Laporan_ Riskesdas2013.PDF

BKKBN. (2012). Bimbingan Teknis Kesehatan Reproduksi dan Seksualitas yang Komprehensif yang Diadaptasi oleh BKKBN dari UNESCO. Jakarta: Biro Sains Regional Asia dan Pasifik. Diakses dari http://unesdoc.unesco.org/ images/0022/002296/229673ind.pdf

Dinas Kesehatan Daerah Istimewa Yogyakarta. (2013). Profil Kesehatan Daerah Istimewa Yogyakarta Tahun 2012. Yogyakarta: Dinas Kesehatan Daerah Istimewa Yogyakarta. Diakses dari http://dinkes.jogjaprov.go.id/files/64370-ProfilKes-DIY-2012.pdf

Dinas Kesehatan Kabupaten Kulon Progo. (2016). Profil Kesehatan Kabupaten Kulon Progo Tahun 2016 (Data 2015). Kulon Progo: Dinas Kesehatan Kabupaten Kulon Progo. Diakses dari http://dinkes.kulonprogokab.go.id/index.php?pil $\mathrm{ih}=\mathrm{hal} \& \mathrm{id}=64$

Ghojali, N.A. (2014). Fenomena Pernikahan Dini. BAKTI, 271-THXXI_Januari 2014.

Grose, R.G., Grabe, S., \& Kohfeldt, D. (2014). Sexual Education, Gender Ideologi, and Youth Sexual Empowerment. Journal Of Sex Research, 51(7), 742-753

Human Rights Initiative. (2017). Legal Provisions Relating To Gender Equality \& Sexual \& Gender Based Violence In South Sudan. Diakses dari https://reliefweb.int/sites/reliefweb.int/files/reso urces/Legal\%20Provisions\%20Gender\%20Equa lity $\% 20$ and $\% 20$ SGBV\%20in\%20South\%20Sud an\%202017.pdf

Idele, P., Gillespie, A., Porth, T., Suzuki, C., Mahy, M., Kasedde, S., \& Luo, C. (2014). Epidemiology of HIV and AIDS Among Adolescents: Current Status, Inequities, and Data Gaps. J Acquir Immune Defic Syndr, Volume 66, Suplemen 2, Juli 1.

Kemenkes Republik Indonesia. (2014). Peraturan Menteri Kesehatan Republik Indonesia Nomor 25 Tahun 2014 tentang Upaya Kesehatan Anak. Diakses dari http://kesga.kemkes.go.id/images/pedoman/PM K\%20No.\%2025\%20ttg\%20Upaya\%20Kesehat an\%20Anak.pdf 
Kemenkes Republik Indonesia. (2017). Data dan Informasi: Profil Kesehatan Indonesia 2016. Jakarta: Kementerian Kesehatan Republik Indonesia.

Kernsmith, P.D. \& Jozefowics, D.M.H. (2011). A Gender Sensitive Peer Education Program for Sexual Assault Prevention in the Schools. Children Schools (2011), 33(3): 146-157.

Ketting, E. \& Ivanova, O. (2018). Sexuality Education in Europe and Central Asia: State of the Art and Recent Developments An Overview of 25 Countries. European Network: International Planned Parenthood Federation. Diakses dari https://www.ippfen.org/sites/ippfen/files/201805/Comprehensive\%20Country\%

20Report\%20on\%20CSE\%20in\%20Europe $\% 20$ and $\% 20$ Central\%20Asia_0.pdf

Krohmer, R. (2010). The Reproductive System: The Human Body, How It Works. New York: Infobase Publishing.

Kyilleh, J.M., Tabong, P.T., \& Konlaan, B.B. (2018). Adolescents' Reproductive Health Knowledge, Choices and Factors Affecting Reproductive Health Choices: A Qualitative Study in The West Gonja District in Northern Region, Ghana. BMC International Health and Human Rights, 18:6.

Le Mat, M.L.J. (2017). (S)exclusion in The Sexuality Education Classroom: Young People on Gender and Power Relations. Sex Education, 17(4): 413424.

Li, C., Cheng, Z., Wu,T., Liang, X., Gaoshan, J., Li,L., Hong, P., \& Tang, K. (2017). The Relationships of School-Based Sexuality Education, Sexual Knowledge and Sexual Behaviors-A Study of 18,000 Chinese College Students. Reproductive Health, 14:103.

Matswetu, V.S. \& Bhana, D. (2018). Humhandara and Hujaya: Virginity, Culture, and Gender Inequalities Among Adolescents in Zimbabwe. SAGE Open April-Juni 2018: 1-11.

Muhanguzi, F.K. (2011). Gender and Sexual Vulnerability of Young Women in Africa: Experiences of Young Girls in Secondary Schools in Uganda. Culture, Health \& Sexuality, 13(6): 713-725, Juni 2011.

Ninsiima, A.B., Leye, E., Michielsen, K., Kemigisha, E., Nyakato, V.N., \& Coene, G. (2018). "Girls Have More Challenges; They Need to Be Locked Up": A Qualitative Study of Gender Norms and the Sexuality of Young Adolescents in Uganda. Int. J. Environ. Res. Public Health, 15, 193.

Oladeji, D. \& Ayangunna, J.A. (2017). Media Influence as Predictors of Adolescent's Sexual Risky Behaviour in Nigeria. MOJ Womens Health 2017, 5(1): 00112.

Parmawati, I. (2015). Pengaruh Pendidikan Kesehatan Reproduksi Berbasis Kesetaraan Gender dalam Meningkatkan Pengetahuan, Sikap, dan Efikasi Diri Remaja Putri di Wilayah Kerja Puskesmas Temon 1 Kulon Progo Yogyakarta (Tesis). Program Pascasarjana Fakultas Kedokteran,
Universitas Gadjah Mada, Yogyakarta, Indonesia.

Pringle, J., Mills, K.L., McAteer, J., Jepson, R., Hogg, E., Anand, N., \& Blakemore, S. (2017). The Physiology of Adolescent Sexual Behaviour: A Systematic Review. Cogent Social Sciences, 3: 1368858.

Rahmawati, N.T., Hastuti, J., \& Suriyanto, R.A. (2017). Relationship Between Somatotype and Age at Menarche Among Adolescent Girls in Yogyakarta Province, Indonesia. Pak. J. Nutr., 16(5): 351-358.

Sammon, E.M., Martinez, M., Jagmag, M., \& Wahyudi, R. (2017). Overview of Promising Practices in Adolescent Programming in Indonesia by UNICEF (and other partners): Document Review. Oxford Policy Management Ltd. Diakses dari https://www.unicef.org/indonesia/Overview_of _Promising_Practices_in_Adolescent_Program ming_in_Indonesia.pdf

Sugihastuti \& Saptiawan, I.H. (2010). Gender dan Inferioritas Perempuan: Praktik Kritik Sastra Feminis. Yogyakarta: Pustaka Pelajar.

Timreck, E. (2004). Placing Gender at The Heart of Sexuality Education. SIECUS Report; Summer, 32, 3; ProQuest Research Library.

UNESCO. (2018). International Technical Guidance on Sexuality Education An Evidence-Informed Approach. Diakses dari http://unesdoc.unesco.org/images/ 0026/002607/260770e.pdf

WHO. (2018). Fact Sheet Adolescent Pregnancy. Diakses dari http://www.who.int/mediacentre/factsheets/fs36 4/en/ 